\title{
Principal component analysis of linear measures of young horses national champions of Mangalarga Marchador breed
}

\author{
Mariana de Castro Sellani ${ }^{1}$ (D) Adalgiza Souza Carneiro de Rezende ${ }^{2}$ (i) Emmanuel Arnhold Em $^{1}$ \\ Adriana Santana do Carmo $^{1}$ (D) Arthur dos Santos Mascioli ${ }^{1}$ (D) Laydiane de Jesus Mendes $^{3}$ (D) \\ Kate Moura da Costa Barcelos ${ }^{1^{*}}$
}

'Escola de Veterinária e Zootecnia, Departamento de Zootecnia, Universidade Federal de Goiás (UFG), 74691-750, Goiânia, GO, Brasil. E-mail: kate@ufg.br. "Corresponding author.

${ }^{2}$ Universidade Federal de Minas Gerais (UFMG), Belo Horizonte, MG, Brasil.

${ }^{3}$ Instituto Federal do Norte de Minas Gerais (IFNMG), Montes Claros, MG, Brasil.

ABSTRACT: The conformation is directly related to the quality of the movements, and can direct the selection by equine aptitude. This study aimed to identify which are the morphometric measurements that explain the total variance available in the marcha batida and picada gaits of young Mangalarga Marchador horses. Analyses were performed by evaluating 20 linear measurements of 420 champion horses. Measures were separated by gender (male-M and female-F), type of marcha, (batida-MB e picada-MP) and divided into eight age groups. Principal component analysis (PCA) was used to identify which measurements were most important in determining marcha variance by selecting principal component $(P C)$ which sum of eigenvalues was able to explain the minimum percentage of $80 \%$ of the total variation. The PC number varied randomly according to age groups, being 2 to 3 in both genders in MP, 3 to 4 for $M-M B$, and up to 5 for $F$-MB, suggesting lower overall variability in $M P$, and higher in $F-M B$. There was no defined pattern concerning the amount of PC per age group, demonstrating that each category may have independent variations. Although, some repetitions of variables occurred similarly in different ages, sexes, and marcha types, the responsibility for the highest occurrence of variation was the posterior cannon and gaskin length. The significant variance in the length of these segments, regardless of gender, age, and marcha, and the fact they are not measured daily suggested there is not only a lack of standardization of these segments, but there is also size compensation among them since the group evaluated is composed of breed champions. Key words: marcha, conformation, morphometric measurements, variance.

Análise de componentes principais das medidas lineares de equinos jovens campeões nacionais da raça Mangalarga Marchador

RESUMO: A conformação pode estar diretamente relacionada a qualidade dos movimentos direcionando a seleção dos equinos por aptidão. Objetivou-se identificar quais medidas lineares explicam a variância total disponivel nas marchas batida e picada em cavalos jovens da raça Mangalarga Marchador. As análises foram realizadas pela avaliação de 20 medidas lineares de 420 equinos campeões de exposições, separados por sexo (macho-M e fêmeas-F), tipo de marcha (batida-MB e picada-MP) e oito grupos etários. Utilizou-se análise de componentes principais (ACP) para identificar quais características eram mais importantes na determinação da variância das marchas, selecionando aquelas contidas em CP, cuja soma de autovalores foi capaz de explicar o percentual mínimo de $80 \%$ da variação total. O número de CP variou de acordo com as faixas etárias, sendo de 2 a 3 em Me F-MP, de 3 a 4 para M-MB e até 5 para F-MB, o que sugere menor variação em animais de MP, e maior em F-MB. Não houve padrão na quantidade de CP por classe etária demonstrando variações independentes entre categorias. A maior variância geral foi explicada pelo comprimento de canela posterior e perna. A grande variância no comprimento desses segmentos, independentemente de sexo, idade, tipo de marcha e o fato dos mesmos não serem mensurados cotidianamente, sugere que não ocorre somente a ausência de padronização, mas também há compensação de tamanho entre eles, visto que se avaliou apenas animais campeões da raça. Palavras chave: marcha, conformação, morfometria, variância.

\section{INTRODUCTION}

The Mangalarga Marchador (MM) breed has 600,000 registered animals (MAPA, 2016), and is the fastest growing breed of horses in the country, generating great employment and income for Brazilian equine culture. They present marcha as gait, which give them the characteristic of being smooth horses and differentiate them from trot animals, which take their selection for marcha gait and leisure contests. 
Gaited horses perform a wide range of different stride (NICODEMUS \& CLAYTON, 2003), which are supposed to require several skeletal adaptations (STAIGER et al., 2016). Therefore, different types of four-beat stepping gaits can be comparatively studied. The "marcha" is the main characteristic attributed to the MM breed mainly because, in general, it does not have suspension times between the change of the members that touch the ground. According to BARCELOS et al. (2016), this is a comfortable gait for the rider and has two subtypes called "marcha batida", in which the horse spends more time on diagonal supports, and "marcha picada", in which the horse spends more time on lateral supports or triple supports. Individuals with different gaits standarts, marcha batida or picada, do not come from different populations, and may be born with one phenotype or another (FONSECA et al., 2017). This gait characteristic of MM results from neuromotor coordination of movements, training and appropriate morphometric measures (PINTO et al., 2005).

Body size and conformation are critically important characteristics in almost all breeds of horses and, presumably, are under strong selection. Many breed registries select horses based on functional criteria and encourage horse breeding with body types more suitable to specific functions. Correct skeletal conformation is the body type as a determinant key (BROOKS et al., 2010).

Gaited horses have morphological differences when compared to trothorses. Comparisons of individual measurements demonstrate that trot horses have smaller widths between the eyes and jaw, as well as proportionally longer segments in the forelimbs, and thinner circumferences in the lower parts of these limbs (STAIGER et al., 2016). The selection of the MM breed gave the animals a smaller head, shorter body length, a larger diameter of the bone rays and an increase in the size of these animals within the standard values of the breed (PINTO et al., 2005). However, similarities and differences in conformation within the race can be noticed in relation to gender and type of marcha, especially regarding measurements related to limb flexion, frequency, and stride length (SANTIAGO et al., 2014). Similarly, it is assumed that differences may also occur that explain the total variance in different age groups due to the maturity of certain body regions in relation to others during different growth phases of the horse.

The purpose of this study was to identify which linear measures explain the highest cumulative proportion of the total variance available in young Mangalarga Marchador horses of different genders, ages, and types of marcha (batida and picada).

\section{MATERIALS AND METHODS}

There were analysed using the morphometric data of 20 linear conformation measurements of 420 animals of the MM breed, holders of titles of champion, reserved champion, $1^{\text {st }}, 2^{\text {nd }}, 3^{\text {rd }}, 4^{\text {th }}$ or $5^{\text {th }}$ prize in marcha picada (MP) and marcha batida (MB) in the conventional breed contest held at the $33^{\text {rd }}$ and $34^{\text {th }}$ National Exhibition of MM, corresponding to the years 2014 and 2015, in the Bolívar de Andrade Park in Belo Horizonte, MG. The analyses were carried out with information from stallion and female animals, from 15 to 60 months of age. All classified animals had already secured the title of champion or reserved champions in several regional classification exhibitions for the national exhibition.

The linear measurements collected were: height at withers (HTW), height at croup (HC), height at back (HB), body length (BL), head length (HL), neck length (NL), shoulder length (SL), back-loin length (BLL), croup length (CL), croup width (CPW), barrel height (girth-back distance) (BH), chest width (CTW), head width (HDW), arm length (AL), forearm length (FL), cannon length of forelimb (CLFL), pastern length of forelimb (PLFL), thigh length (TL), gaskin length (GL) and cannon length of hindlimb (CLHL). All measurements were made using a hipometer and measuring tape graduated in centimetres, as described by BARCELOS (2016). The data descriptive analysis is shown in table 1 .

Before the data analysis, Bartlett's sphericity tests were conducted, and the adequacy measure of the Kaiser-Meyer-Olkin (KMO) sample was estimated, which presented a p-value of 0.01 , and an index of 0.91 , respectively. These values demonstrated that the PCA proposed in the present research is adequate for the database in question.

For data analysis, these were grouped according to gender (M-male and F-female), type of marcha (MB and MP), and age range, as shown in table 2. The G5 subgroup of M-MP was excluded of the analyses because it presented only one individual in this category.

The importance of variables for determining variability was evaluated through PCA. The original data were centralized and resized by subtracting the average and dividing by standard deviation (auto scaling) to avoid bias in the analysis of main components due to the different magnitudes of the variables. Only the $\mathrm{PC}$ in which the sum of the variance ratio exceeded $80 \%$ was selected. Variables that comprise the other PCs were discarded, as they made an insignificant contribution to the discrimination of groups (MORRISON, 1976, and 
Table 1 - Mean, maximum, minimum, standard deviation, and coefficient of variation of the morphometric measurements collected in 420 Mangalarga Marchador horses from 15 up to 60 months of age, national champions in the years 2014 and 2015.

\begin{tabular}{|c|c|c|c|c|c|}
\hline Variables & Average & Maximum & Minimum & SD & $\mathrm{VC}$ \\
\hline HTW & 146.88 & 157.00 & 130.00 & 5.43 & 3.69 \\
\hline $\mathrm{HB}$ & 137.99 & 146.00 & 126.00 & 4.58 & 3.32 \\
\hline $\mathrm{HC}$ & 144.66 & 153.00 & 135.00 & 3.99 & 2.76 \\
\hline BL & 146.58 & 158.00 & 130.00 & 5.93 & 4.04 \\
\hline HL & 57.12 & 62.00 & 47.00 & 2.51 & 4.40 \\
\hline NL & 63.13 & 70.00 & 57.00 & 2.86 & 4.53 \\
\hline SL & 48.96 & 64.00 & 41.00 & 3.50 & 7.14 \\
\hline BLL & 43.25 & 49.00 & 36.00 & 3.04 & 7.04 \\
\hline CL & 50.16 & 56.00 & 42.00 & 2.73 & 5.44 \\
\hline CPW & 49.07 & 54.00 & 40.00 & 2.89 & 5.89 \\
\hline $\mathrm{BH}$ & 59.31 & 65.00 & 39.00 & 3.70 & 6.24 \\
\hline CTW & 36.24 & 64.00 & 29.00 & 4.57 & 12.62 \\
\hline HDW & 19.42 & 23.00 & 17.00 & 1.17 & 6.04 \\
\hline $\mathrm{AL}$ & 27.87 & 47.50 & 23.00 & 3.72 & 13.33 \\
\hline FL & 43.07 & 51.00 & 35.50 & 3.44 & 8.00 \\
\hline CLFL & 27.66 & 30.50 & 17.50 & 1.76 & 6.36 \\
\hline PLFL & 12.13 & 13.50 & 10.00 & 0.84 & 6.89 \\
\hline $\mathrm{TL}$ & 33.85 & 39.00 & 28.00 & 3.36 & 9.92 \\
\hline GL & 44.12 & 55.00 & 36.00 & 6.29 & 14.25 \\
\hline CLHL & 42.99 & 53.00 & 31.50 & 8.14 & 18.94 \\
\hline
\end{tabular}

SD- standard deviation; VC - variation coefficient; HTW - height at withers ; HB - height at back ; HC - height at croup; BL - body length ; HL - head length ; NL - neck length ; SL - shoulder length; BLL - back-loin length ; CL - croup length ; CPW - croup width ; BH - barrel height (girth-back distance); CTW - chest width ; HDW -head width ; AL arm length ; FL - forearm length ; CLFL- cannon length of forelimb ; PLFL - pastern length of forelimb ; TL- thigh length ; GL- gaskin length; CLHL - cannon length of hindlimb

employed by BARBOSA, 1993). The variables that were not eliminated in this process were those that were considered the most important to discriminate the variation of the group. The software R (R CORE TEAM, 2019) was used to obtain the components by gender, type of marcha gait and age range.

\section{RESULTS AND DISCUSSION}

The number of PC justifying $80 \%$ of the phenotypic variation reported in the different types of marcha varied according to the age range, being 2 to 3 in both sexes in the MP animals (Tables 3 and 4),

Table 2 - Number of Mangalarga Marchador horses, national champions in the years 2014 and 2015, submitted to the collection of morphometric measurements in each of the analyzed subgroups.

\begin{tabular}{|c|c|c|c|c|c|c|c|c|c|c|}
\hline & & G1 & $\mathrm{G} 2$ & G3 & G4 & G5 & G6 & G7 & G8 & Total \\
\hline Type of Marcha & Gender & \multicolumn{9}{|c|}{--1- } \\
\hline MB & M & 11 & 30 & 22 & 20 & 14 & 14 & 13 & 21 & 145 \\
\hline MB & $\mathrm{F}$ & 11 & 36 & 19 & 25 & 9 & 20 & 11 & 22 & 153 \\
\hline MP & M & 3 & 8 & 3 & 7 & 1 & 8 & 14 & 11 & 55 \\
\hline MP & F & 3 & 10 & 5 & 10 & 4 & 12 & 10 & 13 & 67 \\
\hline \multicolumn{2}{|c|}{----------------------Total------------------- } & 28 & 84 & 49 & 62 & 28 & 54 & 48 & 67 & 420 \\
\hline
\end{tabular}

G1=15.0-18.9 months; G2=19.0-24.9 months; G3=25.0-30.9 months; G4=31.0-36.9 months; G5=37.0-42.9 months; G6=43.0-48.9 months; G7=49.0-54.9 months; G8=55.0-60.9; $\mathrm{MB}=$ Marcha Batida; $\mathrm{MP}=$ Marcha Picada; $\mathrm{M}=$ Stallion; $\mathrm{F}=\mathrm{Females}$ 
Table 3 - Loadings of principal components (PC) that explained at least $80 \%$ of the proportion of the accumulated variance, by age group, in marcha picada gait national champions females of the Mangalarga Marchador breed in the years 2014 and 2015.

\begin{tabular}{|c|c|c|c|c|c|c|c|c|c|c|c|}
\hline \multicolumn{3}{|c|}{------------G1(15-18.9m)----------- } & \multicolumn{3}{|c|}{----------G2(19-24.9m)---------- } & \multicolumn{3}{|c|}{---------G3(25-30.9m)----------- } & \multicolumn{3}{|c|}{----------G4(31-36.9m)---------- } \\
\hline HTW & 0.782 & PC1 & CLHL & 0.52 & PC1 & CLHL & 0.26 & PC1 & CLHL & 0.74 & PC1 \\
\hline $\mathrm{CL}$ & 0.308 & PC1 & GL & 0.52 & PC1 & GL & 0.509 & PC1 & GL & 0.501 & PC1 \\
\hline BLL & 0.284 & PC1 & BL & 0.325 & PC1 & $\mathrm{TL}$ & 0.26 & PC1 & TL & 0.232 & PC1 \\
\hline CTW & 0.562 & PC2 & HTW & 0.473 & PC2 & $\mathrm{BL}$ & 0.681 & PC2 & $\mathrm{BH}$ & 0.786 & PC2 \\
\hline HL & 0.411 & PC2 & CLHL & 0.46 & PC2 & HB & 0.331 & PC2 & BLL & 0.332 & PC2 \\
\hline $\mathrm{BH}$ & 0.323 & PC2 & HB & 0.41 & PC2 & CLHL & 0.271 & PC2 & HTW & 0.286 & PC2 \\
\hline \multirow[t]{3}{*}{ HB } & 0.323 & PC2 & & & & & & & HB & 0.599 & PC3 \\
\hline & & & & & & & & & $\mathrm{HC}$ & 0.426 & PC3 \\
\hline & & & & & & & & & HTW & 0.317 & PC3 \\
\hline \multicolumn{3}{|c|}{-----------G5(39-42.9m)------------ } & \multicolumn{2}{|c|}{----G6(43-48.9m)----- } & & \multicolumn{2}{|c|}{-----G7(49-54.9m)----- } & & \multicolumn{2}{|c|}{----G8(55-60.9m)----- } & \\
\hline CLHL & 0.625 & PC1 & CLHL & 0.589 & PC1 & CLHL & 0.629 & PC1 & CLHL & 0.714 & PC1 \\
\hline $\mathrm{AL}$ & 0.453 & PC1 & CTW & 0.516 & $\mathrm{PC} 1$ & GL & 0.47 & PC1 & GL & 0.524 & PC1 \\
\hline GL & 0.356 & PC1 & GL & 0.448 & $\mathrm{PC} 1$ & FL & 0.313 & $\mathrm{PC} 1$ & TL & 0.256 & PC1 \\
\hline AL & 0.765 & PC2 & CTW & 0.592 & PC2 & $\mathrm{AL}$ & 0.43 & PC2 & $\mathrm{HB}$ & 0.574 & PC2 \\
\hline FL & 0.388 & PC2 & SL & 0.397 & PC2 & CLFL & 0.408 & PC2 & HTW & 0.509 & PC2 \\
\hline \multirow[t]{4}{*}{ CLHL } & 0.358 & PC2 & GL & 0.339 & PC2 & $\mathrm{HC}$ & 0.356 & PC2 & $\mathrm{HC}$ & 0.425 & $\mathrm{PC} 2$ \\
\hline & & & & & & HTW & 0.614 & PC3 & HL & 0.726 & PC3 \\
\hline & & & & & & $\mathrm{HB}$ & 0.408 & PC3 & BL & 0.361 & PC3 \\
\hline & & & & & & $\mathrm{BH}$ & 0.312 & PC3 & CLFL & 0.235 & PC3 \\
\hline
\end{tabular}

HTW-height at withers; HC-height at croup; HB-height at back; BLL-back-loin length; CLHL-cannon length of hindlimb; TL-thigh length; BH-barrel height (girth-back distance); CL-croup length; FL-forearm length; GL-gaskin length; BL-body length; AL-arm length; SL-shoulder length; CTW-chest width; HL-head length; CLFL-cannon length of forelimb.

Table 4 - Loadings of principal components (PC) that explained at least $80 \%$ of the proportion of the accumulated variance, by age group, in marcha picada gait national champions males of the Mangalarga Marchador breed, in the years 2014 and 2015.

\begin{tabular}{|c|c|c|c|c|c|c|c|c|c|c|c|}
\hline \multicolumn{3}{|c|}{-------'G1(15-18.9m)-------- } & \multicolumn{3}{|c|}{---'G2(19-24.9m)-- } & \multicolumn{3}{|c|}{--'G3(25-30.9m)-- } & \multicolumn{3}{|c|}{ - } \\
\hline CLHL & 0.664 & PC1 & CLHL & 0.75 & $\mathrm{PC} 1$ & CLHL & 0.744 & PC1 & CLHL & 0.706 & PC1 \\
\hline GL & 0.592 & $\mathrm{PC} 1$ & GL & 0.501 & PC1 & GL & 0.488 & $\mathrm{PC} 1$ & GL & 0.593 & PC1 \\
\hline $\mathrm{FL}$ & 0.266 & PC1 & $\mathrm{TL}$ & 0.3 & $\mathrm{PC} 1$ & $\mathrm{TL}$ & 0.259 & $\mathrm{PC} 1$ & TL & 0.214 & PC1 \\
\hline BL & 0.62 & PC2 & TL & 0.488 & $\mathrm{PC} 2$ & HB & 0.476 & PC2 & BL & 0.617 & $\mathrm{PC} 2$ \\
\hline HB & 0.31 & $\mathrm{PC} 2$ & BL & 0.414 & $\mathrm{PC} 2$ & FL & 0.42 & PC2 & SL & 0.375 & $\mathrm{PC} 2$ \\
\hline CLHL & 0.284 & $\mathrm{PC} 2$ & GL & 0.295 & $\mathrm{PC} 2$ & $\mathrm{HC}$ & 0.339 & $\mathrm{PC} 2$ & NL & 0.346 & $\mathrm{PC} 2$ \\
\hline \multicolumn{3}{|c|}{---------G5(39-42.9m)--------- } & \multicolumn{3}{|c|}{-----------G6(43-48.9m)--------- } & \multicolumn{3}{|c|}{---------G7(49-54.9m)--------- } & \multicolumn{3}{|c|}{----------G8(55-60.9m)-------' } \\
\hline \multirow[t]{9}{*}{ HTW } & 1 & PC1 & CLHL & 0.739 & $\mathrm{PC} 1$ & CLHL & 0.695 & $\mathrm{PC} 1$ & CLHL & 0.744 & PC1 \\
\hline & & & GL & 0.515 & $\mathrm{PC} 1$ & GL & 0.469 & PC1 & GL & 0.45 & $\mathrm{PC} 1$ \\
\hline & & & $\mathrm{TL}$ & 0.294 & $\mathrm{PC} 1$ & TL & 0.346 & $\mathrm{PC} 1$ & $\mathrm{TL}$ & 0.332 & PC1 \\
\hline & & & $\mathrm{BL}$ & 0.883 & $\mathrm{PC} 2$ & $\mathrm{AL}$ & 0.57 & $\mathrm{PC} 2$ & CPW & 0.613 & $\mathrm{PC} 2$ \\
\hline & & & HTW & 0.278 & PC2 & $\mathrm{BL}$ & 0.322 & PC2 & $\mathrm{CL}$ & 0.4 & $\mathrm{PC} 2$ \\
\hline & & & BLL & 0.237 & $\mathrm{PC} 2$ & HTW & 0.314 & $\mathrm{PC} 2$ & HTW & 0.279 & $\mathrm{PC} 2$ \\
\hline & & & & & & $\mathrm{FL}$ & 0.441 & PC3 & $\mathrm{BL}$ & 0.578 & PC3 \\
\hline & & & & & & CLHL & 0.43 & PC3 & $\mathrm{AL}$ & 0.471 & $\mathrm{PC} 3$ \\
\hline & & & & & & CPW & 0.405 & $\mathrm{PC} 3$ & CLFL & 0.4 & PC3 \\
\hline
\end{tabular}

HTW-height at withers; HC-height at croup; HB-height at back; BLL-back-loin length; CLHL-cannon length of hindlimb; TL-thigh length; CL-croup length; FL-forearm length; GL-gaskin length; BL-body length; AL-arm length; NL-neck length; CPW-croup width; SL-shoulder length. 
from 3 to 4 for M-MB (Table 5), and from 3 to 5 for F-MB (Table 6). This suggested that it was necessary to use a larger number of variables to discriminate the animals of MB regarding to less variables used to discriminate animals of MP, which denotes a higher level of standardization in the group of champion animals of MP in both genders.

The F-MB group showed the greatest variation with up to five PC. PINTO et al. (2005) observed an even greater number of PC finding seven components to explain a minimum percentage of $80 \%$ of the total variation of horses less than 12 months old. Therefore, it is suggested that the younger the animal, the greater the variance of the body parts.

Divergences between studies may have occurred because they evaluate different age ranges and different morphofunctional measures. The number of PC used to assess variance by PINTO et al.
(2005) was also much higher, which may be due to the fact that they evaluated linear, angular and perimeter measurements, or because they used another age range in which growth is much more relevant in changing proportions. However, it is mostly because in the present study we worked with national champion animals, which makes the group previously evaluated here selected to present a standardization consistent with the best specimens of the MM breed.

There was no defined pattern in relation to the amount of PC by age range demonstrating that different variables can discriminate among animals of different ages, which can be justified by the fact that in the majority of vertebrates the growth of the body parts occurs in an allometric way.

Measures that contributed with the highest proportion of the total variance of the subgroups and, therefore, were identified more frequently in $\mathrm{PC} 1$,

Table 5 - Loadings of principal components (PC) that explained at least $80 \%$ of the proportion of the accumulated variance. by age group. in marcha batida gait national champions males of the Mangalarga Marchador breed in the years 2014 and 2015.

\begin{tabular}{|c|c|c|c|c|c|c|c|c|c|c|c|}
\hline \multicolumn{3}{|c|}{----------G1(15-18.9m)----------- } & \multicolumn{3}{|c|}{---------G2(19-24.9m)--------- } & \multicolumn{3}{|c|}{---------G3(25-30.9m)------------ } & \multicolumn{3}{|c|}{------------G4(31-36.9m)----------- } \\
\hline HTW & 0.478 & PC1 & CLHL & 0.676 & PC1 & CLHL & 0.076 & $\mathrm{PC} 1$ & CLHL & 0.685 & PC1 \\
\hline $\mathrm{HC}$ & 0.402 & PC1 & GL & 0.563 & PC1 & GL & 0.557 & PC1 & GL & 0.542 & PC1 \\
\hline $\mathrm{HB}$ & 0.343 & PC1 & $\mathrm{TL}$ & 0.283 & PC1 & $\mathrm{TL}$ & 0.234 & PC1 & $\mathrm{TL}$ & 0.283 & $\mathrm{PC} 1$ \\
\hline BLL & 0.666 & $\mathrm{PC} 2$ & BL & 0.698 & $\mathrm{PC} 2$ & $\mathrm{BL}$ & 0.602 & $\mathrm{PC} 2$ & BL & 0.599 & $\mathrm{PC} 2$ \\
\hline CLHL & 0.489 & PC2 & HTW & 0.324 & $\mathrm{PC} 2$ & HTW & 0.422 & $\mathrm{PC} 2$ & CLHL & 0.455 & $\mathrm{PC} 2$ \\
\hline $\mathrm{TL}$ & 0.315 & PC2 & $\mathrm{HC}$ & 0.274 & PC2 & HB & 0.332 & PC2 & HB & 0.297 & PC2 \\
\hline $\mathrm{BH}$ & 0.739 & PC3 & HTW & 0.479 & PC3 & FL & 0.628 & PC3 & GL & 0.608 & PC3 \\
\hline CL & 0.372 & PC3 & BL & 0.463 & PC3 & $\mathrm{HC}$ & 0.345 & PC3 & CLHL & 0.493 & PC3 \\
\hline FL & 0.323 & PC3 & HB & 0.394 & PC3 & $\mathrm{AL}$ & 0.324 & PC3 & TL & 0.296 & PC3 \\
\hline $\mathrm{BH}$ & 0.47 & PC4 & & & & & & & & & \\
\hline BLL & 0.379 & PC4 & & & & & & & & & \\
\hline CL & 0.367 & PC4 & & & & & & & & & \\
\hline \multicolumn{3}{|c|}{----------G5(39-42.9m)----------- } & \multicolumn{3}{|c|}{---------G6(43-48.9m)--------- } & \multicolumn{3}{|c|}{-----------G7(49-54.9m)---------- } & \multicolumn{3}{|c|}{------------G8(55-60.9m)----------- } \\
\hline CLHL & 0.719 & PC1 & $\mathrm{BL}$ & 0.487 & PC1 & $\mathrm{BL}$ & 0.396 & $\mathrm{PC} 1$ & CLHL & 0.727 & PC1 \\
\hline GL & 0.574 & PC1 & $\mathrm{HC}$ & 0.426 & PC1 & HB & 0.388 & $\mathrm{PC} 1$ & GL & 0.499 & PC1 \\
\hline TL & 0.243 & PC1 & HTW & 0.356 & PC1 & HTW & 0.385 & PC1 & $\mathrm{TL}$ & 0.334 & PC1 \\
\hline $\mathrm{BL}$ & 0.524 & PC2 & $\mathrm{BL}$ & 0.679 & PC2 & CL & 0.707 & PC2 & $\mathrm{BL}$ & 0.54 & $\mathrm{PC} 2$ \\
\hline $\mathrm{HC}$ & 0.45 & $\mathrm{PC} 2$ & $\mathrm{BH}$ & 0.338 & PC2 & $\mathrm{BH}$ & 0.415 & PC2 & HTW & 0.376 & PC2 \\
\hline NL & 0.351 & $\mathrm{PC} 2$ & HB & 0.319 & $\mathrm{PC} 2$ & HTW & 0.266 & $\mathrm{PC} 2$ & CL & 0.346 & $\mathrm{PC} 2$ \\
\hline $\mathrm{BH}$ & 0.507 & PC3 & $\mathrm{HC}$ & 0.319 & PC2 & BL & 0.641 & PC3 & $\mathrm{HC}$ & 0.591 & PC3 \\
\hline BL & 0.442 & PC3 & FL & 0.513 & PC3 & $\mathrm{TL}$ & 0.304 & PC3 & GL & 0.523 & PC3 \\
\hline \multirow[t]{4}{*}{ GL } & 0.412 & PC3 & $\mathrm{CPW}$ & 0.391 & PC3 & $\mathrm{CL}$ & 0.3 & PC3 & $\mathrm{TL}$ & 0.33 & PC3 \\
\hline & & & TL & 0.381 & $\mathrm{PC} 3$ & HB & 0.441 & PC4 & & & \\
\hline & & & & & & $\mathrm{CL}$ & 0.337 & PC4 & & & \\
\hline & & & & & & $\mathrm{BL}$ & 0.333 & PC4 & & & \\
\hline
\end{tabular}

HTW-height at withers; HC-height at croup; HB-height at back; BLL-back-loin length; CLHL-cannon length of hindlimb; TL-thigh length; BH-barrel height (girth-back distance); CL-croup length; FL-forearm length; GL-gaskin length; BL-body length; AL-arm length; NL-neck length; CPW-croup width. 
were CLHL and LL that occurred in the subgroups F-MP $(\mathrm{G} 2,4,7,8)$ (Table 3), M-MP (G2, 4, 6, 7, 8) (Table 4), M-MB (G2, 3, 4, 5, 8) (Table 5), and F-MB (G1, 2 $, 3,4,5,6,8$ ) (Table 6). This suggested that these segments be measured in the technical evaluation routine, as the absence of such measures may contribute to their variance in the studied population. The subgroups G1, G3 of M-MP and G5 of F-MP presented results similar to those described above; however, the number of animals in these categories is small, which may have interfered with the results.

It is possible that the lengths of longer hindlimbs contribute to the variation of the gaited phenotype, but this result is difficult to separate from sexual dimorphism (STAIGER et al., 2016). The fact is that these measurements have not been taken daily in the MM breed, which, possibly, led to the lack of standardization in these segments. However, the values reported can be related to the movement and stride length of the hindlimbs, since stride range is a constant concern in the selection of exhibition animals, since values of cannon and gaskin length can be complementary.

MEIRA et al. (2013), after analyzing the database of the Brazilian Association of Mangalarga Marchador Horse Breeders (ABCCMM) discarded the height measures at the withers, body length, thorax perimeter, shoulder length, neck length, head length and hip width, as it shows little data variability and had a significant correlation with the other measures. Discrepancy and differences in results that were reported in the present study in relation to the research of MEIRA et al. (2013) is not only due to the fact that the referred authors have worked with animals older than 36 months, but also showed that the data collection method and the evaluator can

Table 6 - Loadings of principal components (PC) that explained at least $80 \%$ of the proportion of the accumulated variance, by age group, in marcha batida gait national champions females of the Mangalarga Marchador breed in the years 2014 and 2015.

\begin{tabular}{|c|c|c|c|c|c|c|c|c|c|c|c|}
\hline \multicolumn{3}{|c|}{------------G1(15-18.9m)---------- } & \multicolumn{3}{|c|}{---------G2(19-24.9m)--------- } & \multicolumn{3}{|c|}{--------G3(25-30.9m)--------- } & \multicolumn{3}{|c|}{-------------G4(31-36.9m)------------ } \\
\hline CLHL & 0.56 & $\mathrm{PC} 1$ & CLHL & 0.725 & $\mathrm{PC} 1$ & CLHL & 0.621 & PC1 & CLHL & 0.736 & $\mathrm{PC} 1$ \\
\hline GL & 0.47 & $\mathrm{PC} 1$ & GL & 0.545 & $\mathrm{PC} 1$ & GL & 0.595 & $\mathrm{PC} 1$ & GL & 0.573 & $\mathrm{PC} 1$ \\
\hline NL & 0.399 & $\mathrm{PC} 1$ & $\mathrm{TL}$ & 0.305 & PC1 & HB & 0.301 & $\mathrm{PC} 1$ & $\mathrm{TL}$ & 0.245 & PC1 \\
\hline $\mathrm{HC}$ & 0.499 & $\mathrm{PC} 2$ & $\mathrm{BL}$ & 0.446 & PC2 & $\mathrm{HB}$ & 0.544 & PC2 & $\mathrm{BL}$ & 0.552 & $\mathrm{PC} 2$ \\
\hline $\mathrm{BL}$ & 0.415 & PC2 & HTW & 0.434 & PC2 & HTW & 0.402 & $\mathrm{PC} 2$ & $\mathrm{HB}$ & 0.518 & PC2 \\
\hline HTW & 0.357 & PC2 & $\mathrm{HC}$ & 0.425 & PC2 & CLHL & 0.381 & $\mathrm{PC} 2$ & HTW & 0.38 & $\mathrm{PC} 2$ \\
\hline CPW & 0.781 & PC3 & BL & 0.608 & PC3 & FL & 0.703 & PC3 & $\mathrm{BL}$ & 0.642 & PC3 \\
\hline $\mathrm{AL}$ & 0.286 & $\mathrm{PC} 3$ & HTW & 0.441 & $\mathrm{PC} 3$ & NL & 0.373 & $\mathrm{PC} 3$ & HB & 0.539 & $\mathrm{PC} 3$ \\
\hline $\mathrm{HC}$ & 0.25 & PC3 & FL & 0.408 & $\mathrm{PC} 3$ & BLL & 0.317 & $\mathrm{PC} 3$ & $\mathrm{AL}$ & 0.351 & PC3 \\
\hline \multicolumn{3}{|c|}{------------G5(39-42.9m)---------- } & \multicolumn{3}{|c|}{--------G6(43-48.9m)-------- } & \multicolumn{3}{|c|}{--------G7(49-54.9m)-------- } & \multicolumn{3}{|c|}{-------------G8(55-60.9m)--------- } \\
\hline CLHL & 0.768 & $\mathrm{PC} 1$ & CLHL & 0.838 & PC1 & HTW & 0.646 & PC1 & CLHL & 0.712 & $\mathrm{PC} 1$ \\
\hline GL & 0.471 & $\mathrm{PC} 1$ & GL & 0.36 & $\mathrm{PC} 1$ & $\mathrm{HC}$ & 0.295 & PC1 & GL & 0.512 & $\mathrm{PC} 1$ \\
\hline TL & 0.343 & $\mathrm{PC} 1$ & TL & 0.228 & PC1 & HB & 0.484 & PC1 & TL & 0.32 & $\mathrm{PC} 1$ \\
\hline GL & 0.571 & $\mathrm{PC} 2$ & BL & 0.683 & $\mathrm{PC} 2$ & CL & 0.694 & $\mathrm{PC} 2$ & HTW & 0.438 & $\mathrm{PC} 2$ \\
\hline $\mathrm{BL}$ & 0.46 & PC2 & HTW & 0.374 & PC2 & $\mathrm{BL}$ & 0.385 & $\mathrm{PC} 2$ & $\mathrm{HC}$ & 0.399 & $\mathrm{PC} 2$ \\
\hline CLHL & 0.41 & PC2 & $\mathrm{BH}$ & 0.266 & PC2 & BLL & 0.35 & $\mathrm{PC} 2$ & HB & 0.373 & PC2 \\
\hline $\mathrm{BL}$ & 0.623 & $\mathrm{PC} 3$ & $\mathrm{BH}$ & 0.654 & $\mathrm{PC} 3$ & NL & 0.537 & PC3 & $\mathrm{BH}$ & 0.68 & $\mathrm{PC} 3$ \\
\hline BLL & 0.344 & PC3 & HL & 0.348 & PC3 & BL & 0.487 & PC3 & SL & 0.377 & PC3 \\
\hline \multirow[t]{7}{*}{ SL } & 0.342 & $\mathrm{PC} 3$ & BLL & 0.293 & $\mathrm{PC} 3$ & SL & 0.373 & PC3 & $\mathrm{HC}$ & 0.32 & PC3 \\
\hline & & & $\mathrm{BL}$ & 0.451 & PC4 & CTW & 0.643 & PC4 & BL & 0.768 & PC4 \\
\hline & & & HTW & 0.446 & PC4 & $\mathrm{HB}$ & 0.445 & $\mathrm{PC} 4$ & $\mathrm{BH}$ & 0.524 & PC4 \\
\hline & & & $\mathrm{HB}$ & 0.347 & PC4 & CLHL & 0.33 & PC4 & HB & 0.204 & PC4 \\
\hline & & & GL & 0.594 & PC5 & SL & 0.623 & PC5 & & & \\
\hline & & & HB & 0.349 & PC5 & CTW & 0.438 & PC5 & & & \\
\hline & & & $\mathrm{HC}$ & 0.322 & PC5 & $\mathrm{BH}$ & 0.296 & PC5 & & & \\
\hline
\end{tabular}

HTW-height at withers; HC-height at croup; HB-height at back; BLL-back-loin length; CLHL-cannon length of hindlimb; TL-thigh length; BH-barrel height (girth-back distance); CL-croup length; FL-forearm length; GL-gaskin length; BL-body length; AL-arm length; NL-neck length; CPW-croup width; SL-shoulder length. 
significantly influence the results, especially when analyzing the database of an association.

It should be noted that MEIRA et al. (2013), even affirming that the analysis of main components allows identifying characteristics to be eliminated, cites that the choice of characteristics that should be eliminated is a technical decision. Thus, PC analyses should be used with caution in these cases, especially in populations with greater heterogeneity, in other words, different from the ones in this study, national champion animals, which were previously selected in regional exhibitions as the best specimens in their regions.

The variables PLFL and HDW do not explain much of the variance reported in all subgroups. Regarding the length of the pastern, this is possibly due to the fact that ossification of the middle and proximal phalanx occurs up to 30 or 38 weeks; respectively, of the foal's life (SMALLWOOD et al., 1989); therefore, not considering this age range of the studied animals. Likewise, the head width, despite being an endochondral ossification, does not appear to undergo significant changes in animals older than 15 months of age. Therefore, both linear measures can be discarded in later studies in the age group evaluated.

Regarding gender and type of marcha, in F-MP, NL, and CPW have low discriminatory power, as well as HL, BH, and CTW in M-MP; likewise, NL, CTW, CLFL, and AL for M-MB, and also HL and CLFL for F-MB. These variables are possible to be eliminated only in relation to the gender and type of marcha of the groups of champion animals studied.

Although, there are specific conformation patterns for gait in relation to breeds, some marcha breeds still have varying conformation patterns (STAIGER et al., 2016). SANTIAGO et al. (2014) when evaluating linear and angular measurements of adult $\mathrm{MM}$ also reported a difference between gender and type of marcha related to limb flexion, length and frequency of strides. These findings corroborate that the differences in conformation may have occurred due to the different type of gait.

The choice of PC that can be reduced, especially for measurements that require monitoring of defects such as animals that have croup height greater than withers (downhill) or heights previously defined in definitive genealogical record standards, should be interpreted very carefully and based on technical references of animal growth, since the purely mathematical exclusion of certain variables can jeopardize the future registration of many animals, compromising their selection.

\section{CONCLUSION}

The great variance in the length of the evaluated segments occurred regardless of gender, age and type of marcha. Pastern length and head width have a low discriminatory value in all age ranges above 15 months of age, and can thus be discarded. It is suggested to routinely evaluate cannon length of the hindlimb and gaskin, because even in groups of well-standardized champion animals there were segments of higher variability.

\section{ACKNOWLEDGMENTS}

This work was carried out with support from $\mathrm{CNPq}$ Conselho Nacional de Desenvolvimento Científico e Tecnológico - Brazil; Brazilian Association of Mangalarga Marchador Horse Breeders (ABCCMM); Scientific Initiation Program (PIVIC) of the Universidade Federal de Goiás (UFG) and Equine Service Extension Project of UFG.

\section{BIOETHICS AND BIOSSECURITY COMMITTEE APPROVAL}

This project was previously approved by the Animal Use Ethics Committee (CEUA) of Federal University of Minas Gerais (UFMG), under protocol No. 215/2014.

\section{DECLARATION OF CONFLICT OF} INTERESTS

The authors declare no conflicts of interest. The founding sponsors had no role in the design of the study; in the collection, analyses, or interpretation of data; in the writing of the manuscript; or in the decision to publish the results.

\section{AUTHORS' CONTRIBUTIONS}

The authors contributed equally to the article.

\section{REFERENCES}

BARBOSA, C. G. Estudo morfométrico na raça Mangalarga Marchador. Uma abordagem multivariada. 1993. 76p. Dissertação (Mestrado em Zootecnia), Curso de pós-graduação em zootecnia, Universidade Federal de Minas Gerais.

BARCELOS, K. M. C. Estudo morfométrico e do desenvolvimento de potros campeões da raça Mangalarga Marchador. 2016. 201p. Tese (Doutorado em Zootecnia), Área de concentração Produção Animal, Curso de pós-graduação em zootecnia, Universidade Federal de Minas Gerais.

BARCELOS, K. M. C., et al. Prevalence of tarsal diseases in champion Mangalarga Marchador horses in the Marcha Picada Modality and Its Association With Tarsal Angle, J. Eq. Vet. Sci., v.27, p.25-30. 2016. Available from: <https://doi.org/10.1016/j. jevs.2016.07.012>. Accessed: Oct. 12, 2019. doi: 10.1016/j. jevs.2016.07.012

Ciência Rural, v.50, n.12, 2020. 
BROOKS, S. A. Morphological variation in the horse: defining complex traits of body size and shape. Stitching International Foundation for Animal Genetics, Sutter, v.41 (Suppl. 2), p.159-165, 2010. Available from: <https://doi.org/10.1111 /j.1365-2052.2010.02127.x>. Accessed: Oct. 12, 2019 . doi: 10.1111/j.1365-2052.2010.02127.x.

FONSECA, M. G., et al. A Genome-wide association Study Reveals Differences in the Genetic Mechanism of Control of the Two Gait Patterns of the Brazilian Mangalarga Marchador Breed. Journal of Equine Veterinary Science, v.53, 2017, p.64-67. Available from: $<$ https://doi.org/10.1016/j.jevs.2016.01.015>. Accessed: Oct. 12, 2019. doi: 10.1016/j.jevs.2016.01.015.

MAPA. Revisão do Estudo do Complexo do Agronegócio Cavalo, Ministério da Agricultura, Pecuária e Abastecimento. 2016.

MEIRA, C. T. et al. Identification of morphofunctional traits in Mangalarga Marchador horse using principal component analysis. Arq. Bras. Med. Vet. Zootec, v.65, n.6, p.18431848, 2013. Available from: <https://doi.org/10.1590/S010209352013000600036>. Accessed: Oct. 12, 2019. doi: 10.1590/ S0102-09352013000600036.

MORRISON D. F. Multivariate statistical methods. 2.ed. New York: McGraw-Hill Company, 1976. 415p.

NICODEMUS, M. C. e CLAYTON, H. M. Temporal variables of four-beat, stepping gaits of gaited horses. Appl. Anim. Behav. Sci., v.80, p.133-142, 2003. Available from: <https://doi.org/10.1016/ S0168-1591(02)00219-8>. Accessed: Oct. 12, 2019. doi: 10.1016/ S0168-1591(02)00219-8.
PINTO, L. F. B. et al. Análise multivariada das medidas morfométricas de potros da raça Mangalarga Marchador: análise de componentes principais. Revista Brasileira de Zootecnia, v.34, n.2, p.589-599, 2005. Available from: <https://doi.org/10.1590/ S1516-35982005000200029>. Accessed: Oct. 12, 2019. doi: 10.1590/S1516-35982005000200029.

R CORE TEAM. R: A language and environment for statistical computing. R Foundation for Statistical Computing. 2020. Vienna, Austria. Available from: <https://www.R-project.org/>. Accessed: Oct. 12, 2019.

SANTIAGO, J. M, et al. Comparação entre as medidas morfométricas de equinos Mangalarga Marchador de marcha batida e marcha picada. Escola de Veterinária, Universidade Federal de Minas Gerais, Belo Horizonte, MG. Arq. Bras. Med. Vet. Zootec., v.66, n.2, p.635-639, 2014. Available from: $<$ https:// doi.org/10.1590/1678-41626870>. Accessed: Oct. 12, 2019. doi: $10.1590 / 1678-41626870$.

SMALLWOOD, J. E., et al. Xeroradiographic study of the developing equine fore digit and metacarpophalangeal region from birth to six months of age. Veterinary Radiology and Ultrasond. v.30, n.3, p.98-110, 1989. Available from: <https:// doi.org/10.1111/j.1740-8261.1989.tb00753.x>. Accessed: Oct. 12, 2019. doi: 10.1111/j.1740-8261.1989.tb00753.x.

STAIGER, E. A., et al. Morphological variation in gaited Horse Breeds. Journal of Equine Veterinary Science, v.43, p.55-65, 2016. Available from: <https://doi.org/10.1016/j. jevs.2016.04.096>. Accessed: Oct. 12, 2019. doi: 10.1016/j. jevs.2016.04.096 